\title{
THE USE OF TREASURE HUNT GAME TOWARD THE STUDENTS' VOCABULARY MASTERY AT ISLAMIC SENIOR HIGH SCHOOL
}

\author{
Nurpatima \\ Universitas Islam Negeri (UIN) Alauddin Makassar \\ nurfatimaabdullahlI@gmail.com \\ Kamsinah \\ Universitas Islam Negeri (UIN) Alauddin Makassar \\ kamsinah@uin-alauddin.ac.id \\ St. Nurjannah Yunus Tekeng \\ Universitas Islam Negeri (UIN) Alauddin Makassar \\ Jannah.yustek@gmail.com
}

DOI: https://doi.org/10.24252/elties.v2i1.11439

\begin{abstract}
The researcher aims at findings the effectiveness using Treasure Hunt Game toward students' vocabulary mastery at Islamic Senior High School of Muhammadiyah Palampang. This research was conducted at the class X MIA 1 and X MIA 2. The sample of this research was 50 students from 280 populations. The control class was taken from class X MIA 1, while the experimental class was from X MIA 2. The number of the sample in each class was 25 students. Quasi-experimental design was applied in this research with two group pre-test and post-test design. The instrument used to collect data was a vocabulary test. Research findings showed that the experimental class got score on pre-test with the mean score 44,2. After giving treatment the students got change, they got score with the mean score 59,9. The result of the data analysis indicated that there was a change of the students' vocabulary mastery after being taught using Treasure Hunt Game. It was proved by the result of the statistical analysis of the level significance $\mathrm{P}=0.05$ with degree of freedom $(\mathrm{df})=48$ indicated that the $\mathrm{t}$ test values of the students' vocabulary mastery $(2,53)$ was higher than the t-table $(2,01)$. Based on the result of analysis, the researcher concludes that using Treasure Hunt Game was effective toward the students' vocabulary mastery at the first grade students of Islamic Senior High School of Muhammadiyah Palampang, because Treasure Hunt Game give a lot of fun, the students enjoy the learning without any preasure. Than, Treasure Hunt Game stimulates students engagement in learning process. If students enjoy the learning process, they were enthusiastic enough to involve and compete each other in learning process.
\end{abstract}

Keywords: Treasure Hunt Game, Vocabulary mastery, First Grade Students 
Volume 2, Number 1, March 2020

\section{INTRODUCTION}

Vocabulary plays an important role in learning a foreign language. It is one element that links the four language skills (speaking, listening, reading, and writing) all together. In order to communicate well in a foreign language, students should acquire an adequate number of words and should know how to use them accurately (Sorayaie-Azar, 2012: 252). Vocabulary needs more attention in learning English. If students have good vocabulary, they will attain all components of four basic language skills. Students not only need grammar as main aspect but also need vocabulary to conduct communication. Theoretically, it is stated by Thornbury (2002:13) "Without grammar very little can be conveyed, without vocabulary nothing can be conveyed". Thornbury's statement shows that vocabulary has an essential part in doing communication by using particular English language.

The importance of vocabulary was also mentioned by Jawariah (2005: 3). She stated that teaching English vocabulary as an element of language is considered the most important factor. If the students are lack of vocabulary, they will get difficulty to master all of the English skills. Therefore, the student cannot grasp someone's ideas that are transmitted to them.

Using English, both written and oral language, the students' difficulty is about lack of vocabulary. Based on the researcher's interview which was conducted to some first grade students of Senior high school, almost all of them have difficulties in memorizing vocabulary. It is difficult for them to recall the lists of vocabulary which they have memorized. They said that, the vocabulary is not saved in their long term memory because it was not meaningful for them. Thus, it needs more attention from the teacher to make the conveying of the vocabulary process easier to grasp, more fun to learn, and more meaningful for students. The teacher shall utilize a technique which can develope students' vocabulary mastery in English to conduct success teaching process. The teacher has to be a creative teacher in teaching. Therefore, the student feel easy in memorizing vocabulary. Based on this case, one of the ways in teaching easy and fun vocabulary is by using games.

Nurpahmi and Sari (2016) conducted a research at the seventh grade students' of SMPN 1 Turatea Jeneponto regency to find out the effectiveness of using Buzzword Technique in Teaching Vocabulary for the Seventh Grade Students of SMPN 1 Turatea Jeneponto Regency and to know the students' interest in using Buzzword. This research employed quasi-experimental design with 
two group pre-test and post-test design. The finding of using Buzzword Technique was effective and interesting in teaching Vocabulary.

Ardiana (2010) also ran a research to 76 students from SMPN 1 Gembong in Academic Year of 2009/2010. The study dealt with the use of Treasure Hunt Game in teaching English spelling to junior high school students. The result showed that the mean of the students' achievement in learning English spelling through Treasure Hunt Game had significant improvement. Based on this conclusion, it is recommended that English teachers can apply Treasure Hunt Game as a media in teaching English spelling for junior high school students.

Relevant research also conducted by Wulansari (2016) who had done a study with research participants were all of the students of class VII-B at SMPN 2 Gondang, Tulungagung. This research was aimed at finding out the improvement of the Seventh students' Comprehension in Reading Descriptive Text by Using Treasure Hunt Game, by using Classroom Action Research method. This research showed that the use of Treasure Hunt Game was successful in improving students' comprehension in reading.

The findings of some researchers above focused on conducting Treasure Hunt Game in developing students' ability in spelling and reading. In this research, the researcher focused on usingTreasure Hunt Game toward the students' vocabulary mastery, specifically for the Senior High School. The objective of this research was to find out the effectiveness of the use of Treasure Hunt Games toward students' vocabulary mastery for the first grade students at Islamic Senior High School of Muhammadiyah Palampang.

\section{RESEARCH METHOD}

This research was formulated as a quasi-experimental design which applied Nonequivalent Control Group Design. The population of this research was all students of Islamic senior High School of Muhammadiyah Palampang-Bulukumba, that was 280 students from thethreegrades. This research used purposive sampling technique in taking sample. The sample of this research was 50 students. The control class took from class X MIA 1, while the experimental class was from class X MIA 2. The number of the sample in each class was 25 students.

The instrument of this research was test which based on context knowledge of vocabulary with the indicators namely the ability of the students in knowing the meaning of vocabulary based on the context and using vocabulary in an appropriate context. The tests covered noun (Nature and 


\section{Volume 2, Number 1, March 2020}

its' Surroundings, Professions, and Places) that consisted of pre-test and post-test. In this research, the researcher usedmultiple choice and fill in the blank vocabulary test. Multiple choice consisted of 30 items and fill in the blank consisted of 10 items.

Before giving the treatment, the researcher administered a pre-test to both experiment and control class, to find out students prior knowledge about basic vocabulary. In this case, the students were given 40 test itemsfor 60 minutes. After conducting the pre-test, the treatment was given to both experiment and control class in eight meetings. The experimentclass was given treatment by applying Treasure Hunt Games. In each meeting, the researcherbegan the class by explaining the material, then devide the students into some groups to compete to find out the treasure(word) in limited time. While in control class, the researcher used technique which the teacher used to do in teaching vocabulary. After conducting the treatment, both experiment and control class were given post-test. It aimed to measure whether the use of Treasure Hunt Games was effective toward students' vocabulary mastery.

After collecting the data, the next step of the research was analyzing the data. The data were analyzed quantitatively.

\section{FINDINGS AND DISCUSSION}

\section{Findings}

Before giving the treatment, the researcher conducted pre-test to both of experiment and controlled class. The result of the pre-test was acquired to know the students' in mastering the vocabulary. After giving the pre-test, the students' score was calculated and was classified, all the students score of the pre-test both of experimental and control class can be seen in the following table:

Table 1. Classification of Students Pre-test Both of Experimental and Control Class

\begin{tabular}{lccccc}
\hline \multirow{2}{*}{ Classification } & Score & \multicolumn{2}{c}{$\begin{array}{c}\text { Experimental } \\
\text { Group }\end{array}$} & \multicolumn{2}{c}{ Control Group } \\
\cline { 3 - 6 } & & F & P(\%) & F & P (\%) \\
\hline Excellent & $96-100$ & 0 & $0 \%$ & 0 & $0 \%$ \\
Very Good & $86-95$ & 0 & $0 \%$ & 0 & $0 \%$ \\
Good & $76-85$ & 0 & $0 \%$ & 0 & $0 \%$ \\
Fair Good & $66-75$ & 6 & $24 \%$ & 2 & $8 \%$ \\
Fair & $56-65$ & 0 & $0 \%$ & 2 & $8 \%$
\end{tabular}




\begin{tabular}{lccccc} 
Poor & $36-55$ & 9 & $36 \%$ & 8 & $32 \%$ \\
Very Poor & $0-35$ & 10 & $40 \%$ & 13 & $52 \%$ \\
\hline \multicolumn{2}{c}{ TOTAL } & $\mathbf{2 5}$ & $\mathbf{1 0 0 \%}$ & $\mathbf{2 5}$ & $\mathbf{1 0 0 \%}$ \\
\hline
\end{tabular}

Table 1 is the students' pre-test score of both classes(experiment and control class). It shows that, the average percentage of the pre-test in both classes is under the good classification,they are only in fair good.In comparing Both of classes, it can be seen that the higest percentage in experimental class is in very poor classification (40\%), while in the control class is in the very poor classification $(52 \%)$ as well.

The teaching vocabulary to the experimental class used Treasure Hunt Game, while in the control class was taught by using conventional method (discussion) that their teacher used to do, both of the classes was given post-test to find out whether there is a differentiationafter giving the treatment or not. The score of the students' post-test in both of classes can be seen in the table 2:

Table 2. Classification of Students Post-test Both of Experimental and Control Class

\begin{tabular}{|c|c|c|c|c|c|}
\hline \multirow[t]{2}{*}{ Classification } & \multirow[t]{2}{*}{ Score } & \multicolumn{2}{|c|}{ Experimental } & \multicolumn{2}{|c|}{ Control Group } \\
\hline & & $\mathbf{F}$ & $\mathbf{P}(\%)$ & $\mathbf{F}$ & $\mathbf{P}(\%)$ \\
\hline Excellent & $96-100$ & 0 & $0 \%$ & 0 & $0 \%$ \\
\hline Very Good & $86-95$ & 0 & $0 \%$ & 0 & $0 \%$ \\
\hline Good & $76-85$ & 3 & $12 \%$ & 1 & $4 \%$ \\
\hline Fair Good & $66-75$ & 4 & $16 \%$ & 3 & $12 \%$ \\
\hline Fair & $56-65$ & 7 & $28 \%$ & 6 & $24 \%$ \\
\hline Poor & $36-55$ & 10 & $40 \%$ & 10 & $40 \%$ \\
\hline Very Poor & $0-35$ & 1 & $4 \%$ & 5 & $20 \%$ \\
\hline \multicolumn{2}{|c|}{ TOTAL } & 25 & $100 \%$ & 25 & $100 \%$ \\
\hline
\end{tabular}

Table 2 shows that there was a change in the distribution of scores in both classes compared to the distribution of scores in the pre-test. The grades of the students both in the experimental and control class had spread on the classification of very poor to good. At this post-test score, the percentage of good classification in the experimental class (12\%) was higher than the control class $(4 \%)$.

At the lowest classification, which was very poor, the percentage of the experimental class (4\%) are lower than the control class (20\%).In addition, in this classification, there was a change in the level of percentage of pre-test and post-test in the experimental class. Where, in the pre-test, the very poor classification was the highest percentage (see table 1). However, in the post-test, the 
Volume 2, Number 1, March 2020

very poor was the lowest percentage. It showed that there is a change in scores after applying the Treasure Hunt Game to the experimental class.

After calculating the result of students' pre-test and post-test of experimental and control group by formula, the mean score and standard deviation can be presented in the table below:

Table 3. Mean Score and Standard Deviation of Pre-test and Post-test

\begin{tabular}{|c|c|c|c|c|c|}
\hline \multirow[b]{2}{*}{ Group } & \multicolumn{2}{|c|}{ Mean Score } & \multirow[b]{2}{*}{ Range } & \multicolumn{2}{|c|}{ Standard Deviation } \\
\hline & Pre-Test & $\begin{array}{c}\text { Post- } \\
\text { Test }\end{array}$ & & Pre-Test & $\begin{array}{l}\text { Post- } \\
\text { Test }\end{array}$ \\
\hline Experimental & 44,2 & 59,9 & $-15,9$ & 17,34 & 12,62 \\
\hline Control & 40,8 & 50,2 & $-9,4$ & 15,45 & 14,39 \\
\hline
\end{tabular}

Table 4.3, showed that there was an increase in the value of the students' vocabulary mastery seen in the mean score on the experimental class with disputes in the value of 15,9 between the post-test and pre-test. While the mean score in the controlled class only had a difference of 9.4.

The significance of the students' score between the experimental and the control class in pretest and post-test could be known by using t-test. The result of t-test can be seen in table as follows:

Table 4. Distribution the Value of T-test and T-table in The Pre-test

\begin{tabular}{ccc}
\hline Variable & $\begin{array}{c}\text { T-test } \\
\text { Value }\end{array}$ & $\begin{array}{c}\text { T-table } \\
\text { Value }\end{array}$ \\
\hline Pre-test & 0,73 & 2,01
\end{tabular}

The table showed, the result of the t-test of pre-test was 0,73 and the t-table was 2,01.By comparing the result of score in the both classes, it could be said that, when the result of the t-test was smaller than the t-table, it indicated that there was no significance among the students result of their prior ability toward vocabulary mastery and it was appropriate to continue the research. The table above showed that there was no significance between students' score in the pre-test because the data analysis above showed that the t-test was smaller than the table $(0.73<2.01)$, therefore the research could be continued.

After conducting the research, the post-test was be given to the students. Then, the T-test was determine in order to measure students' improvement in mastering vocabulary, to find out whether the result of two classes scores were significant or not. The t-test and t-table analysis of the posttest were shown in the following table. 
Table 5. Distribution the Value of T-test and T-table in The Post-test

\begin{tabular}{ccc}
\hline Variable & $\begin{array}{c}\text { T-test } \\
\text { Value }\end{array}$ & $\begin{array}{c}\text { T-table } \\
\text { Value }\end{array}$ \\
\hline Post-test & 2,53 & 2,01 \\
\hline
\end{tabular}

After finding the T-test value,the T-test was compared with the T-test to see the significant difference between the experiment class and the control class, whether the experiment was effective or not.

The table above showed that, t-test value was higher than t-table. The result of the t-test shows that there was a significant difference between the $t$-test and the $t$-table $(2.53>2.01)$. The researcher concluded that the t-test value was higher than t-table. The result of the t-test statistical analysis showed that there was a significant different between the experimental class and control class. The statement was proved by the t-test value (2.53) which higher than t-table value (2.01), at the level of significant 0,05 and the degree of freedom $\left(\mathrm{N}_{1}+\mathrm{N}_{2}\right)-2=(25+25)-2=48$

To find out more about whether this is effective or not, it must do the test of effectiveness as follow:

$$
\begin{aligned}
& R\left(\theta_{2}, \theta_{1}\right)=\frac{\operatorname{Var} \theta_{1}}{\operatorname{Var} \theta_{2}} \\
& R\left(\theta_{2}, \theta_{1}\right)=\frac{12,62}{14.39} \\
& R\left(\theta_{2}, \theta_{1}\right)=0,87
\end{aligned}
$$

If $\mathrm{R}>1$, relatively $\theta_{2}$ is efficient than $\theta_{1}$, whereas if $\mathrm{R}<1$, relatively $\theta_{1}$ is more efficient than $\theta_{2}$. The value of $\mathrm{R}$ is $0.87(\mathrm{R}<1)$. so that it can be said $\theta_{1}$ (Treasure Hunt Game technique) is more efficient than $\theta_{2}$ (conventional technique).

\section{Discussion}

The result of this study showed that the students' scores in the experimental class were higher than the contrroled class after the application of Treasure Hunt Game in the experimental class.

The alternative hypothesis of this research would be accepted if the t-test is higher than the $t$ table.If the $t$-test is smaller than the t-table, the alternative hypothesis is rejected. The result of the 


\section{Volume 2, Number 1, March 2020}

data analysis was the t-test was higher than the t-table value (see table 4.5). Based on the result, the $H_{1}$ was accepted. In other words, there was a differentiation after applying Treasure Hunt Gametoward the students' vocabulary mastery.

The analysis of the effectiveness by using effectivity tests shows that the teaching in the experimental class is more effective than in the control class. It was shown from the $\mathrm{R}$ value on the effectiveness test is smaller than $1(0.87<1)$. Thus, relatively, it indicated that the use of the Treasure Hunt Game was more effective than the teaching methods commonly applied by their teachers.

The result of this study indicated that Treasure Hunt Game is one type of games that was quite effective to facilitate the students to master English vocabulary because of two factors. The first was because it had a lot of fun, as Hadfield (1990: 4) said that game is as an activity with rules, a goal and an element of fun. The element of fun in games provides the learners more life situation with more chance to express their ideas in their own ways but under the rule.

In applying the game, the students were as if they were not studying, but they are just playing. They enjoy the learning process without any pressure. It indicates that having fun can facilitate students to be easier in learning something. Wechselberger (2013) stated that with playing games, learners do not think about their worries and escape daily routines, which gives them space to enjoy themselves. Based on nerve studies, student comfort levels have a very important impact on the transmission and storage of information in the brain (Anggoro, 2014). Wills (2007) also stated that the brain and the body of the human respond positively to someone who is laugh which release endorphins, epinferin(adrenaline) and dopamine, and increases the volume of oxigen in breathing process.

The second factor was a game stimulates students engagement in learning process. If students enjoy the learning process, they were enthusiastic enough to involve and compete each other in learning process.Lewis (2004: 123) said that the benefit of games are encouraging the student to learn English because it is fun and make them want to have experiment, discover and interact with their environment. When students involves in learning environments which is enriched and with various sensory stimuli, students will pay greater attention to the material and they will feel that the information is relevant to their lives.

Beside that, Providing any kind of interesting and new experiences is one way that can help students to learn vocabulary become easier in remembering the words and can motivate them in 
class. Game can give big opportunity to students to express their opinion and feelings. In this research, the researcher using Treasure Hunt Game which is a teaching technique that involve students in learning process, especially the students physical activity. Beside that, this game can increase students' ideas in thinking and ability to understand the text guidance. It can be said that Treasure Hunt Game can increase students' motivation in learning and can improve their memorizing ability because it is meaningful for them.

In summary, based on the quantitative analysis and some empirical evidence above, the researcher asserted that using Treasure Hunt Game toward students' vocabulary masteryat the first grade students of Islamic Senior High School of Muhammadiyah Palampang was effective.

\section{CONCLUSION}

Based on the result of data analysis, research finding, and discussion above, the researcher concluded that teaching vocabulary by using Treasure Hunt Game toward Students Vocabulary mastery at the First Grade of Islamic Senior High School of Muhammadiyah Palampang was effective. The data showed that students' competence in the experimental class is higher than in the control class. The t-test for both classes in post-test is 2.53 compared to the t-table with 2.01 for $\alpha 0.05$ with degree of freedom (df) $=48$ since the score of $\mathrm{t}$-test is higher than the score of $\mathrm{t}$ table, alternative hypothesis $\left(\mathrm{H}_{1}\right)$ was accepted and null hypothesis $\left(\mathrm{H}_{0}\right)$ was rejected.

The researcher suggest to next researcher that this thesis is hoped to be one reference in teaching vocabulary and can be a source of information for the future researchers who want to conduct further research that deals with the improvement of other language component or skill by using Treasutre Hunt Game as a technique.

\section{REFERENCES}

Allen, V, F. Technique in Teaching Vocabulary. New York. Oxford University Press. 1983.

Anengsih, NengAan. The Implementation of Treasure Hunt Games in Learning English Vocabulary at the First Grade of SMP N 1 Waled. Thesis SyekhNurjati State Islamic Institute Cirebon. 2017.

Ardiana, Aristi. The Effectiveness of "Treasure Hunt Game” in Teaching English Spelling to the Seventh Year Students of SMPN 1 Gembong in Academic Year of 2009/2010.thesis. 2010.

Arikunto, Suharsimi. Prosedur Penelitian. Jakarta: PT RINEKA CIPTA. 2013. 


\section{Volume 2, Number 1, March 2020}

Brewester, Jean, Geil Ellis, and Denis Girard.The Primary English Teacher's Guide.Penguin English. 1992.

Brown, H. D. Principle of Language Learning and Teaching. New York: 1980.

Celce-Murcia, Marianne.’Language Teaching Approaches: An Overview.” Teaching English as a Second or Foreign Language 2 (2001).

Harmer, J.The Practice of English Language Teaching, Third Edition. London: Longman. 1991.

Harmer, Jeremy. The Principle of English Language Teaching.New York: Longman Group. 2001.

Hatch, E \& Brown, C. Vocabulary, Semantics, and Language Education. 1995.

Hiebert, Elfrieda H, and Michael L Kamil.Teaching and learning Vocabulary: bringing Reaserch to Practice. Routledge, 2005.

Hornby, A.S. et AL.The Advances Learner's Dictionary to Current English ( Second Edition). London: Oxford University Press. 1963.

Indahyanti, Riska. The Implementation of Team Game Tournament of Cooperative Learning Method in Improving Students' Vocabulary Achievement.Thesis FBS UNM. 2010.

Jannah, Miftahul. Using Games in Improving Students' Vocabulary.Thesis UIN SyarifHidayatullah Jakarta. 2011.

Jawariah.Building up Vocabulary Mastery of the Second Year Student of MTS PesantrenAnNahdlah through Translating Test. Thesis UIN Alauddin Makassar. 2005.

Julia, Dobson. Try One of My Games, Washington DC. P 295.

Lewis, G. et al. Games for Children,: New York: Oxford University Press. 2003.

Mulbar, Agusman. Teaching Vocabulary through Poem to the Second Years Students of SMU Negeri II Makassar. Faculty of Teacher Training and Education. Makassar Muhammadiyah University. 2002.

Mushaf Muslimah. Bandung: Jabal. 2010.

Mutakabbir, Amran. The Effectiveness of Using Narrating Picture to Improve the Speaking Ability of the Second Year Students at SMPN 1 Sinjai Selatan. Thesis UIN Alauddin Makassar. 2014.

Nurpahmi, Sitti and Sari, Anita Puspita. Using Buzzword Technique in the Teaching of Vocabulary to the Seventh Grade Students' of SMPN 1 Turatea Jeneponto Regency. Thesis UIN Alauddin Makassar. 2016.

Oxford Learner's Pocket Dictionary. New York: Oxford University Press. 2008.

Riahipour, P, \& Saba, Z. ESP Vocabulary Instruction: Investigating the Effect of Using a Game Oriented Teaching Method for Learners of English for Nursing. Journal of Language Teaching and Research. 2012. 
Schimitt, Norbert, and Michael Mc Carthy. Vocabulary: Description, Acquisition and Pedagogy. Cambridge University Press. 1997.

Sorayaie Azar, A. The Effect of Games on EFL Learners' Vocabulary Learning Strategies. International Journal of Applied and Basic Science. 2012.

Sudarmi. Enriching the Vocabulary of the Second Year Students of SMA Negeri 1 Duampanua through Crossword Puzzles. Thesis FBS UNM. 2008.

Sudijono, Anas. Pengantar Statistik Pendidikan. Jakarta: rajawali Pers. 2015.

Sugiyono. Metode Penelitian Pendidikan. Bandung: Alfabeta. 2017.

Thornbury, Scoot. How to Teach Vocabulary. Pearson Education Limited. Year of 2009/2010 (thesis). 2010.

Wulansari, Rina. Using Treasure Hunt Game to Improve the Seventh Grade Students' Comprehension in Reading Descriptive Textat SMPN 2 Gondang, Tulungagung. Thesis IAIN of Tulungagung. 2016. 